\title{
Macronutrient metabolism by the human gut microbiome: major fermentation by- products and their impact on host health
}

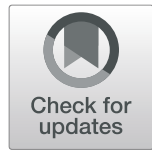

\author{
Kaitlyn Oliphant ${ }^{*}$ (D) and Emma Allen-Vercoe
}

\begin{abstract}
The human gut microbiome is a critical component of digestion, breaking down complex carbohydrates, proteins, and to a lesser extent fats that reach the lower gastrointestinal tract. This process results in a multitude of microbial metabolites that can act both locally and systemically (after being absorbed into the bloodstream). The impact of these biochemicals on human health is complex, as both potentially beneficial and potentially toxic metabolites can be yielded from such microbial pathways, and in some cases, these effects are dependent upon the metabolite concentration or organ locality. The aim of this review is to summarize our current knowledge of how macronutrient metabolism by the gut microbiome influences human health. Metabolites to be discussed include short-chain fatty acids and alcohols (mainly yielded from monosaccharides); ammonia, branched-chain fatty acids, amines, sulfur compounds, phenols, and indoles (derived from amino acids); glycerol and choline derivatives (obtained from the breakdown of lipids); and tertiary cycling of carbon dioxide and hydrogen. Key microbial taxa and related disease states will be referred to in each case, and knowledge gaps that could contribute to our understanding of overall human wellness will be identified.
\end{abstract}

Keywords: Human gut microbiome, Microbial metabolism, Macronutrients, Human health

\section{Introduction}

The human gut microbiota is a complex ecosystem of microorganisms that inhabits and critically maintains homeostasis of the gastrointestinal (GI) tract [1]. Most of the contributions made by the gut microbiota to the physiology of the human superorganism are related to microbial metabolism [2-4], with bacteria being the largest of these contributors to ecosystem functioning in terms of relative genetic content [2]. In general, microbial metabolism of both exogenous and endogenous substrates to nutrients useable by the host is the direct benefit, but metabolites can also act to modulate the immune system through impacting the physiology and gene expression of host cells $[3,5,6]$. The colon is the major site of this fermentation, as its relatively high transit time and $\mathrm{pH}$ coupled with low cell turnover and redox potential presents more favorable conditions for the proliferation of bacteria [7]. However, that does not preclude the importance of the microbiota at other sites, as for example, the small intestinal microbiota

* Correspondence: koliphan@uoguelph.ca

Department of Molecular and Cellular Biology, University of Guelph, 50 Stone Rd E, Guelph, ON N1G 2W1, Canada has been shown to regulate nutrient absorption and metabolism conducted by the host [8]. Further, the presence of diverse metabolic activity can allow the microbiota to maximally fill the available ecological niches and competitively inhibit colonization by pathogens at all sites [9-11]. The elevated concentrations of the mostly acidic fermentation by-products also locally reduce the $\mathrm{pH}$ to create a more inhospitable environment for these incoming invaders [11]. However, specific fermentation pathways carried out by gut microbes can result in the formation of toxic compounds that have the potential to damage the host epithelium and cause inflammation [12-14].

The three macronutrients consumed in the human diet, carbohydrates, proteins, and fat, can reach the colon upon either escaping primary digestion once the amount consumed exceeds the rate of digestion, or resisting primary digestion altogether due to the inherent structural complexity of specific biomolecules [14-16]. Several factors can influence digestive efficiency, which in turn modulates the substrates available to the gut microbiota for consumption, including the form and size of the food particles (affected by cooking and processing), the composition of 
the meal (affected by the relative ratios of macronutrients and presence of anti-nutrients such as $\alpha$-amylase inhibitors), and transit time [17]. Transit time in particular has been shown to increase the richness and alter the composition of fecal microbial communities [18], which itself results from several variables including diet, physical activity, genetics, drugs (e.g., caffeine and alcohol), and psychological status [19]. The bioavailability of micronutrients to the host can also be influenced by gut microbial metabolic processes. Colonic bacteria can endogenously synthesize essential co-factors for host energy metabolism and regulation of gene expression, such as B vitamins [20]. Another example includes the biotransformation of exogenous plant-derived polyphenols that have anti-oxidant, anticancer, and/or anti-inflammatory properties by the gut microbiota, which improves their uptake by the host [21]. The following review articles on micronutrients are recommended to readers since this topic encompasses a wide scope of material [20,21], as such, the predominant food sources that act as precursors for the most highly concentrated metabolites will be the focus of discussion here. The aim of this review is thus to describe the major microbial fermentation by-products derived from macronutrients and their subsequent impacts on host health.

\section{Primary degradation}

Dietary polysaccharides can be interlinked in complex ways through a diverse array of bonds between monosaccharide units, reflected by the sheer number of carbohydrateactivating enzymes reported to have been found in the human gut microbiome [22]. For example, Bacteroides thetaiotaomicron possesses 260 glycoside hydrolases in its genome alone [23], which emphasizes the evolutionary requirement for adaptation in order to maximize utilization of resistant starch and the assortment of fibers available as part of the human diet. In contrast, human cells produce very few of these enzymes (although they do produce amylase to remove $\alpha$-linked sugar units from starch and can use sugars such as glucose, fructose, sucrose, and lactose in the small intestine) and so rely on gut microbes to harvest energy from the remaining complex carbohydrates [17, 24]. However, once the rate-limiting step of primary degradation is surpassed, the resulting monosaccharides can be rapidly consumed by the gut microbiota with often little interconversion necessary for substrates to enter the Embden-Meyerhof-Parnas pathway, Entner-Doudoroff pathway, or Pentose phosphate pathway for pyruvate and subsequent ATP production [25]. Conversely, dietary proteins are characterized by conserved peptide bonds that can be broken down by proteases; gut bacteria can produce aspartic-, cysteine-, serine-, and metallo-proteases, but in a typical fecal sample, these bacterial enzymes are far outnumbered by proteases arising from human cells [26]. However, the 20 proteinogenic amino acid building blocks require more interconversion steps for incorporation into biochemical pathways in comparison to monosaccharide units, and thus it is not typical for a given gut microbial species to have the capacity to ferment all amino acids to produce energy [27]. Additionally, microbial incorporation of amino acids from the environment into anabolic processes would conserve more energy in comparison to their catabolic use, by relieving the necessity for amino acid biosynthesis [13]. It is for this reason that amino acids are generally not considered to be as efficient of an energy source as carbohydrates for human gut-associated microbes, and thus no surprise that the gut microbiota preferentially consume carbohydrates over proteins depending on the ratio presented to them $[28,29]$. This metabolic hierarchy is analogous to human cells such as intestinal epithelial cells (IECs), in which increased amounts of autophagy occurs when access to microbially derived nutrients is scarce, as shown in germ-free mouse experiments [30]. However, there are notable exceptions to this general rule, as certain species of bacteria have adopted an asaccharolytic lifestyle, likely as a strategy to evade competition (examples included in Table 1).

\section{Pyruvate metabolism}

Once pyruvate is produced, primarily from carbohydrates but also from other substrates, the human gut microbiota has developed several fermentation strategies to further generate energy, which are depicted in Fig. 1. Pyruvate can either be catabolized into succinate, lactate, or acetyl-CoA. However, these intermediates do not reach high concentrations in typical fecal samples, as they can be further metabolized by cross-feeders, producing the short-chain fatty acids (SCFAs) acetate, propionate, and butyrate (Table 1) [33]. These fecal metabolites are the most abundant and well-studied microbial end-products, since their effects are physiologically important: for example, host intestinal epithelial cells (IECs) utilize them as a source of fuel [62]. Indeed, SCFAs contribute approximately $10 \%$ of the caloric content required by the human body for optimal functioning [63]. Butyrate is the most preferred source of energy in this respect; its consumption improves the integrity of IECs by promoting tight junctions, cell proliferation, and increasing mucin production by Goblet cells $[63,64]$. Butyrate also exhibits anti-inflammatory effects, through stimulating both IECs and antigen presenting cells (APCs) to produce the cytokines TGF- $\beta$, IL-10, and IL-18, and inducing the differentiation of naïve $\mathrm{T}$ cells to $\mathrm{T}$ regulatory cells [65]. Acetate and propionate can also be consumed by IECs (though to a much lesser degree than butyrate) and have some antiinflammatory effects $[33,63]$. Both acetate and propionate can dampen pro-inflammatory cytokine production mediated by toll-like receptor (TLR) 4 stimulation, and propionate, similar to butyrate, can induce the differentiation of $\mathrm{T}$ cells to $\mathrm{T}$ regulatory cells $[33,34]$. Excess SCFAs that are 
Table 1 Major genera present in the human gut microbiome and their metabolisms

\begin{tabular}{|c|c|c|c|c|c|}
\hline Phylum & Family & Genus & Substrates & Metabolism & End products \\
\hline Actinobacteria & Bifidobacteriaceae & Bifidobacterium & $\begin{array}{l}\text { Dietary } \\
\text { carbohydrates } \\
\text { HMO } \\
\text { Mucin }\end{array}$ & Bifid shunt pathway & $\begin{array}{l}\text { Acetate } \\
\text { Ethanol } \\
\text { Formate } \\
\text { Lactate }\end{array}$ \\
\hline \multirow[t]{4}{*}{ Bacteroidetes } & Bacteroidaceae & Bacteroides & $\begin{array}{l}\text { Dietary } \\
\text { carbohydrates } \\
\text { HMO } \\
\text { Mucin } \\
\text { Proteins } \\
\text { Succinate }\end{array}$ & $\begin{array}{l}\text { 1,2-Propanediol } \\
\text { pathway' } \\
\text { Acetate production } \\
\text { Ethanol production } \\
\text { Succinate pathway }\end{array}$ & $\begin{array}{l}\text { 1,2-Propanediol } \\
\text { Acetate } \\
\text { Carbon dioxide } \\
\text { and Hydrogen } \\
\text { Ethanol } \\
\text { Formate } \\
\text { Propionate } \\
\text { Succinate }\end{array}$ \\
\hline & Porphyromonadaceae & Parabacteroides ${ }^{W}$ & $\begin{array}{l}\text { Dietary } \\
\text { carbohydrates } \\
\text { Proteins } \\
\text { Succinate }\end{array}$ & $\begin{array}{l}\text { Acetate production } \\
\text { Succinate pathway }\end{array}$ & $\begin{array}{l}\text { Acetate } \\
\text { Carbon } \\
\text { dioxide and } \\
\text { Hydrogen } \\
\text { Formate } \\
\text { Propionate } \\
\text { Succinate }\end{array}$ \\
\hline & Prevotellaceae & Prevotella & $\begin{array}{l}\text { Dietary } \\
\text { carbohydrates } \\
\text { Proteins } \\
\text { Succinate }\end{array}$ & $\begin{array}{l}\text { Acetate production } \\
\text { Succinate pathway }\end{array}$ & $\begin{array}{l}\text { Acetate } \\
\text { Formate } \\
\text { Propionate } \\
\text { Succinate }\end{array}$ \\
\hline & Rikencellaceae & Alistipes $^{W}$ & $\begin{array}{l}\text { Dietary } \\
\text { carbohydrates } \\
\text { Proteins } \\
\text { Succinate }\end{array}$ & $\begin{array}{l}\text { Acetate production } \\
\text { Succinate pathway }\end{array}$ & $\begin{array}{l}\text { Acetate } \\
\text { Carbon } \\
\text { dioxide and } \\
\text { Hydrogen } \\
\text { Formate } \\
\text { Propionate } \\
\text { Succinate }\end{array}$ \\
\hline \multirow[t]{4}{*}{ Firmicutes } & Clostridiaceae & $\begin{array}{l}\text { Clostridium } \\
\text { (Clostridium cluster I) }\end{array}$ & $\begin{array}{l}\text { Ethanol and } \\
\text { Propionate } \\
\text { Lactate } \\
\text { Proteins } \\
\text { Saccharides }\end{array}$ & $\begin{array}{l}\text { 1,2-Propanediol } \\
\text { pathway' } \\
\text { Acetate production } \\
\text { Acrylate pathway } \\
\text { Butyrate kinase } \\
\text { pathway } \\
\text { Ethanol production } \\
\text { Lactate production } \\
\text { Valerate production }\end{array}$ & $\begin{array}{l}\text { 1,2-Propanediol } \\
\text { Acetate } \\
\text { Carbon } \\
\text { dioxide and } \\
\text { Hydrogen } \\
\text { Ethanol } \\
\text { Formate } \\
\text { Lactate } \\
\text { Propionate } \\
\text { Butyrate } \\
\text { Valerate }\end{array}$ \\
\hline & Eubacteriaceae & Eubacterium & $\begin{array}{l}\text { Acetate } \\
\text { Carbon dioxide } \\
\text { and hHydrogen } \\
\text { Formate } \\
\text { Lactate } \\
\text { Methanol } \\
\text { Proteins } \\
\text { Saccharides }\end{array}$ & $\begin{array}{l}\text { Acetogenesis } \\
\text { Acetate production } \\
\text { Butyryl c CoA } \\
\text { transferase pathway } \\
\text { Ethanol production } \\
\text { Lactate production }\end{array}$ & $\begin{array}{l}\text { Acetate } \\
\text { Butyrate } \\
\text { Carbon } \\
\text { dioxide and } \\
\text { Hydrogen } \\
\text { Ethanol } \\
\text { Formate } \\
\text { Lactate }\end{array}$ \\
\hline & Erysipelotrichaceae & Erysipelatoclostridium & $\begin{array}{l}\text { Proteins } \\
\text { Saccharides }\end{array}$ & $\begin{array}{l}\text { Acetate production } \\
\text { Lactate production }\end{array}$ & $\begin{array}{l}\text { Acetate } \\
\text { Carbon } \\
\text { dioxide and } \\
\text { Hydrogen } \\
\text { Formate } \\
\text { Lactate }\end{array}$ \\
\hline & Lachnospiraceae & $\begin{array}{l}\text { Blautia } \\
\text { (Clostridium cluster XIVa) }\end{array}$ & $\begin{array}{l}\text { 1,2-Propanediol } \\
\text { Carbon dioxide } \\
\text { and Hydrogen } \\
\text { Dietary } \\
\text { carbohydrates } \\
\text { Formate } \\
\text { Mucin }\end{array}$ & $\begin{array}{l}\text { 1,2-Propanediol } \\
\text { pathway } \\
\text { Acetogenesis } \\
\text { Acetate production } \\
\text { Ethanol production } \\
\text { Lactate production } \\
\text { Succinate pathway' }\end{array}$ & $\begin{array}{l}\text { Acetate } \\
\text { Carbon } \\
\text { dioxide and } \\
\text { Hydrogen } \\
\text { Ethanol } \\
\text { Formate } \\
\text { Lactate } \\
\text { Propanol } \\
\text { Propionate }\end{array}$ \\
\hline
\end{tabular}


Table 1 Major genera present in the human gut microbiome and their metabolisms (Continued)

\begin{tabular}{|c|c|c|c|c|c|}
\hline Phylum & Family & Genus & Substrates & Metabolism & End products \\
\hline & & & & & Succinate \\
\hline & & $\begin{array}{l}\text { Coprococcus } \\
\text { (Clostridium cluster XIVa) }\end{array}$ & $\begin{array}{l}\text { Acetate } \\
\text { Dietary } \\
\text { carbohydrates } \\
\text { Lactate }\end{array}$ & $\begin{array}{l}\text { Acrylate pathway } \\
\text { Butyrate kinase } \\
\text { pathway } \\
\text { Butyryl CoA:acetyl CoA } \\
\text { transferase pathway } \\
\text { Ethanol production } \\
\text { Lactate production }\end{array}$ & $\begin{array}{l}\text { Acetate } \\
\text { Butyrate } \\
\text { Ethanol } \\
\text { Carbon } \\
\text { dioxide and } \\
\text { Hydrogen } \\
\text { Formate } \\
\text { Lactate } \\
\text { Propionate }\end{array}$ \\
\hline & & $\begin{array}{l}\text { Dorea } \\
\text { (Clostridium cluster XIVa) }\end{array}$ & $\begin{array}{l}\text { Dietary } \\
\text { carbohydrates }\end{array}$ & $\begin{array}{l}\text { Acetate production } \\
\text { Ethanol production } \\
\text { Lactate production }\end{array}$ & $\begin{array}{l}\text { Acetate } \\
\text { Carbon } \\
\text { dioxide and } \\
\text { Hydrogen } \\
\text { Ethanol } \\
\text { Formate } \\
\text { Lactate }\end{array}$ \\
\hline & & $\begin{array}{l}\text { Lachnoclostridium } \\
\text { (Clostridium cluster XIVa) }\end{array}$ & $\begin{array}{l}\text { Proteins } \\
\text { Saccharides }\end{array}$ & $\begin{array}{l}\text { Acetate production } \\
\text { Butyrate kinase } \\
\text { pathway } \\
\text { Ethanol production } \\
\text { Lactate production }\end{array}$ & $\begin{array}{l}\text { Acetate } \\
\text { Butyrate } \\
\text { Carbon } \\
\text { dioxide and } \\
\text { Hydrogen } \\
\text { Ethanol } \\
\text { Formate } \\
\text { Lactate }\end{array}$ \\
\hline & & $\begin{array}{l}\text { Roseburia } \\
\text { (Clostridium cluster XIVa) }\end{array}$ & $\begin{array}{l}\text { 1,2-Propanediol } \\
\text { Acetate } \\
\text { Dietary } \\
\text { carbohydrates }\end{array}$ & $\begin{array}{l}\text { 1,2-Propanediol } \\
\text { pathway } \\
\text { Acetate production } \\
\text { Butyryl CoA:acetyl CoA } \\
\text { transferase pathway } \\
\text { Ethanol production } \\
\text { Lactate production }\end{array}$ & $\begin{array}{l}\text { Acetate } \\
\text { Butyrate } \\
\text { Carbon } \\
\text { dioxide and } \\
\text { Hydrogen } \\
\text { Ethanol } \\
\text { Formate } \\
\text { Lactate } \\
\text { Propanol } \\
\text { Propionate }\end{array}$ \\
\hline & Lactobacillaceae & $\underline{\text { Lactobacillus }}$ & $\begin{array}{l}\text { 1,2-Propanediol } \\
\text { Saccharides }\end{array}$ & $\begin{array}{l}\text { 1,2-Propanediol } \\
\text { pathway } \\
\text { Acetate production } \\
\text { Ethanol production } \\
\text { Lactate production }\end{array}$ & $\begin{array}{l}\text { Acetate } \\
\text { Ethanol } \\
\text { Formate } \\
\text { Lactate } \\
\text { Propanol } \\
\text { Propionate }\end{array}$ \\
\hline & Ruminococcaceae & $\begin{array}{l}\text { Faecalibacterium } \\
\text { (Clostridium cluster IV) }\end{array}$ & Acetate & $\begin{array}{l}\text { Butyryl CoA:acetyl CoA } \\
\text { transferase pathway }\end{array}$ & $\begin{array}{l}\text { Butyrate } \\
\text { Carbon } \\
\text { dioxide and } \\
\text { Hydrogen } \\
\text { Formate }\end{array}$ \\
\hline & & $\begin{array}{l}\text { Ruminiclostridium }{ }^{\mathrm{W}} \\
\text { (Specifically Clostridium cluster IV, which is } \\
\text { currently grouped with Clostridium cluster III) }\end{array}$ & $\begin{array}{l}\text { Dietary } \\
\text { carbohydrates } \\
\text { Proteins }\end{array}$ & $\begin{array}{l}\text { Acetate production } \\
\text { Butyrate kinase } \\
\text { pathway } \\
\text { Ethanol production } \\
\text { Lactate production }\end{array}$ & $\begin{array}{l}\text { Acetate } \\
\text { Butyrate } \\
\text { Carbon } \\
\text { dioxide and } \\
\text { Hydrogen } \\
\text { Ethanol } \\
\text { Formate } \\
\text { Lactate }\end{array}$ \\
\hline & & $\begin{array}{l}\text { Ruminococcus } \\
\text { (Clostridium cluster IV) }\end{array}$ & $\begin{array}{l}\text { Dietary } \\
\text { carbohydrates }\end{array}$ & $\begin{array}{l}\text { Acetate production } \\
\text { Ethanol production } \\
\text { Lactate production } \\
\text { Succinate pathway }\end{array}$ & $\begin{array}{l}\text { Acetate } \\
\text { Ethanol } \\
\text { Formate } \\
\text { Lactate } \\
\text { Succinate }\end{array}$ \\
\hline & Streptococcaceae & Streptococcus ${ }^{\mathrm{NW}}$ & $\begin{array}{l}\text { Mucin } \\
\text { Saccharides }\end{array}$ & $\begin{array}{l}\text { Acetate production } \\
\text { Ethanol production } \\
\text { Lactate production }\end{array}$ & $\begin{array}{l}\text { Acetate } \\
\text { Ethanol } \\
\text { Formate } \\
\text { Lactate }\end{array}$ \\
\hline
\end{tabular}


Table 1 Major genera present in the human gut microbiome and their metabolisms (Continued)

\begin{tabular}{|c|c|c|c|c|c|}
\hline Phylum & Family & Genus & Substrates & Metabolism & End products \\
\hline & Veillonellaceae & Veillonella & $\begin{array}{l}\text { 1,2-Propanediol } \\
\text { Lactate } \\
\text { Proteins } \\
\text { Saccharides } \\
\text { Succinate }\end{array}$ & $\begin{array}{l}\text { 1,2-Propanediol } \\
\text { pathway } \\
\text { Acetate production } \\
\text { Lactate production } \\
\text { Succinate pathway }\end{array}$ & $\begin{array}{l}\text { Acetate } \\
\text { Carbon } \\
\text { dioxide and } \\
\text { Hydrogen } \\
\text { Formate } \\
\text { Lactate } \\
\text { Propanol } \\
\text { Propionate } \\
\text { Succinate }\end{array}$ \\
\hline Proteobacteria & Enterobacteriaceae & Escherichia & $\begin{array}{l}\text { Proteins } \\
\text { Saccharides }\end{array}$ & $\begin{array}{l}\text { 1,2-Propanediol } \\
\text { pathway' } \\
\text { 2,3-Butanediol } \\
\text { production } \\
\text { Acetate production } \\
\text { Ethanol production } \\
\text { Lactate production } \\
\text { Succinate pathway' }\end{array}$ & $\begin{array}{l}\text { 1,2-Propanediol } \\
\text { 2,3-Butanediol } \\
\text { Acetate } \\
\text { Carbon } \\
\text { dioxide and } \\
\text { Hydrogen } \\
\text { Ethanol } \\
\text { Formate } \\
\text { Lactate } \\
\text { Succinate }\end{array}$ \\
\hline
\end{tabular}

Taxa that are listed as part of a 'core' gut microbiota found by Falony et al. are in bold [31]. Those genera that were core components of exclusively the 'Western' cohorts are denoted with a 'W' superscript, whereas the exclusively 'non-Western' ones are denoted with a 'NW' superscript. If the core taxon could not be resolved to the genus level, the bacterial families are bolded. For the bacterial families that do not already contain several core genera, the most commonly described genus of the human gut microbiome for that family is also listed as a representative. Additionally, genera found to be highly prevalent among the human population, yet typically present in low abundance, are underlined [32]. The possible substrates consumed, metabolisms, and metabolites for each genus are listed. These metabolisms were inferred from the following articles [28, 33-61]. Note that many of these metabolisms are species-specific, and only the substrates commonly utilized among species of the genus are listed. Further, only the most abundant metabolites produced from pyruvate catabolism (i.e., saccharolytic processes) are given. When a particular metabolic pathway is denoted with an 'I' superscript, the microorganisms do not possess the full enzymatic pathway, but rather produce the typical intermediate as an end-product instead. Likewise, an 'I/A' indicates species of that genus may possess either the full or half pathway

not metabolized by IECs are transported via the hepatic vein to the liver, where they can be incorporated as precursors into gluconeogenesis, lipogenesis, and cholesterologenesis [62]. Specifically, propionate is gluconeogenic, whereas acetate and butyrate are lipogenic. The ratio of propionate to acetate is thought to be particularly important, as propionate can inhibit the conversion of acetate to cholesterol and fat $[62,66]$. Indeed, propionate administration alone can reduce intra-abdominal tissue accretion and intrahepatocellular lipid content in overweight adults [67]. The role(s) of SCFAs in glucose homeostasis is/are not yet fully elucidated, although preliminary work has additionally suggested a beneficial effect, since plasma insulin levels are inversely related to serum acetate concentrations $[62,68]$.

In addition to SCFAs, small but significant amounts of alcohols, including ethanol, propanol, and 2,3-butanediol, can be formed as end-products of pyruvate fermentation (Table 1; Fig. 1). A further alcohol, methanol, is also produced by the gut microbiota as a result of pectin degradation, demethylation of endogenous cellular proteins for regulation, or vitamin $B_{12}$ synthesis [69] rather than fermentation. Alcohols are transported to the liver, where the detoxification process involves their conversion to SCFAs, although through pathways that yield toxic aldehydes as precursors [69-71]. Higher concentrations of endogenous alcohols are thus thought to be a contributing factor to the development of non-alcoholic fatty liver disease (NAFLD) [70, 72]. Proteobacteria are known to be particularly capable of alcohol generation $[69,72]$, and are, interestingly, positively associated with dysbiosis in inflammatory bowel disease (IBD) [73], a disease in which patients are predisposed to developing NAFLD [74]. However, alcohols can also be detoxified by many members of the gut microbiota via pathways similar to those present in mammalian cells, regulating their concentration [69]. Additionally, methanol can be used as a substrate for methanogenesis or acetogenesis [35, 69, 75], and ethanol can be coupled to propionate for fermentation to the SCFA, valerate (Table 1) [36]. Valerate is a poorly studied metabolite, but it has been shown to inhibit growth of cancerous cells [76] and to prevent vegetative growth of Clostridioides difficile both in vitro and in vivo [36].

\section{Hydrogenotrophy}

The human body may rapidly absorb SCFAs and alcohols, which helps to reduce their nascent concentrations within the colon, allowing for continued favorable reaction kinetics $[15,77]$. In addition, the gaseous fermentation byproducts, carbon dioxide and hydrogen, must also be removed to help drive metabolism forward. The utilization of these substrates is mainly the result of cross-feeding between gut microbiota members, rather than host absorption. Three main strategies for this activity exist in the human gut: (1) acetogens, for example, Blautia spp., convert carbon dioxide plus hydrogen to acetate (further examples included in Table 1); (2) methanogens, namely archaea 


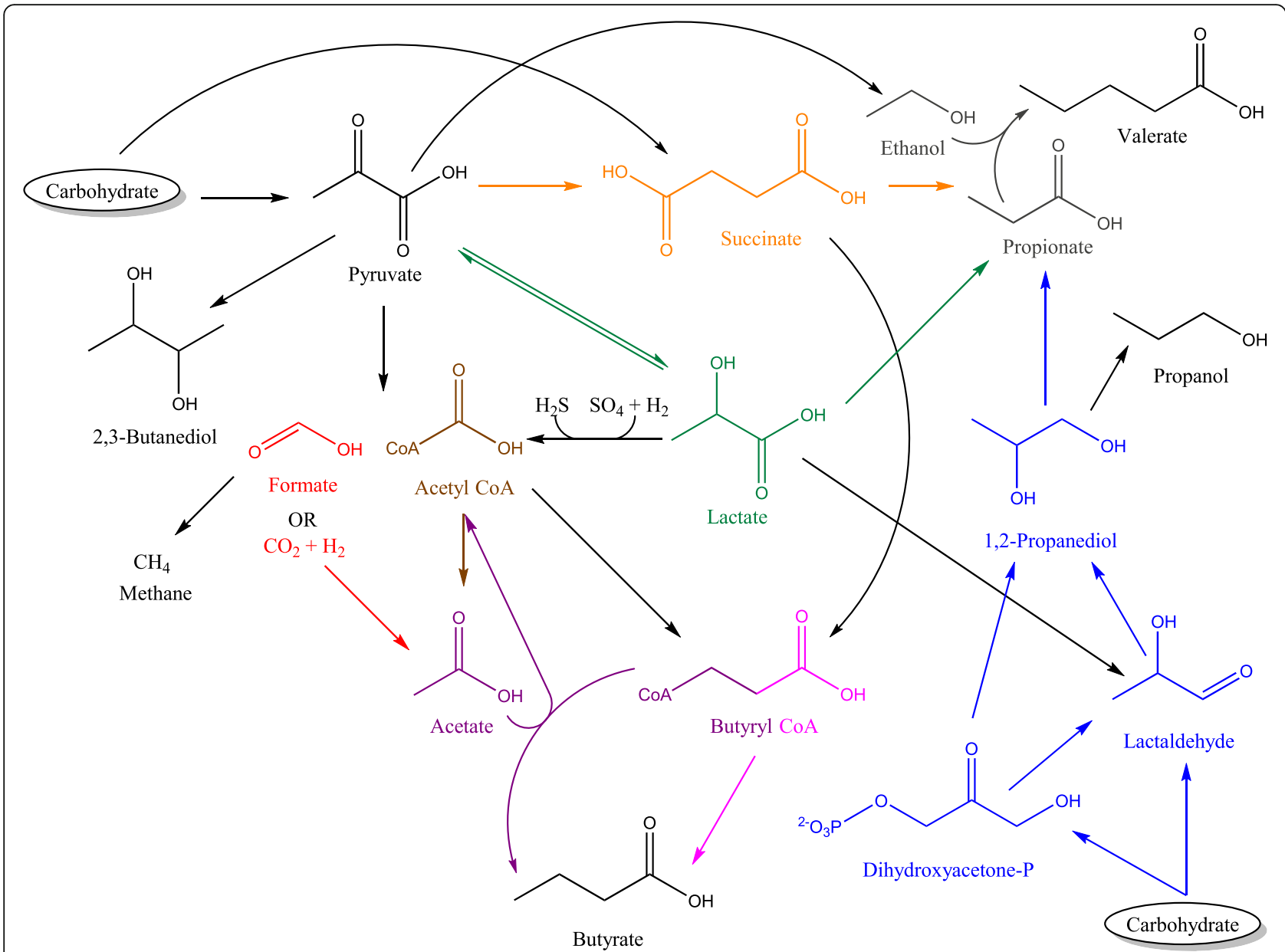

Fig. 1 Strategies of pyruvate catabolism by the human gut microbiome. Carbohydrates are first degraded to pyruvate. Pyruvate may then be converted to succinate, lactate, acetyl CoA + formate/carbon dioxide + hydrogen, ethanol, or 2,3-butanediol. Succinate may, however, also be a direct product of carbohydrate fermentation. Succinate and lactate do not typically reach high concentrations in fecal samples, as they can be further catabolized to produce energy, but certain species do secrete them as their final fermentation end-product, which enables cross-feeding. Acetate is produced by two pathways; (1) through direct conversion of acetyl CoA for the generation of energy (brown) or (2) acetogenesis (red). Formate/carbon dioxide + hydrogen can also be substrates for methanogenesis. Propionate is produced by three pathways; (1) the succinate pathway (orange), (2) the acrylate pathway (green), or (3) the 1,2-propanediol pathway (blue). 1,2-Propanediol is synthesized from lactaldehyde or dihydroxyacetone phosphate, which both are products of deoxy sugar fermentation (e.g., fucose, rhamnose). Alternatively, lactaldehyde can be produced from lactate, or 1,2-propanediol can be fermented to propanol. Propionate can be coupled with ethanol for fermentation to valerate (gray). The precursor for butyrate, butyryl CoA, is generated from either acetyl CoA or succinate. Butyrate is then produced by two pathways; (1) the butyrate kinase pathway (pink) or (2) the butyryl CoA:acetyl CoA transferase pathway (purple). Butyrate-producing bacteria may also cross-feed on lactate, converting it back to pyruvate. Lactate may also be catabolized as part of sulfate reduction

such as Methanobrevibacter, convert carbon dioxide plus hydrogen to methane; and (3) sulfate reducing bacteria, including Desulfovibrio, convert sulfate plus hydrogen to hydrogen sulfide $[15,37]$. A higher abundance of these cross-feeders may improve the overall efficiency of metabolism in the gut; for example, an increase in methanogens is observed in the GI tract of anorexia nervosa patients, which may be a coping strategy by the gut microbiota in response to a lack of food sources [78, 79]. Sulfate-reducing bacteria are the most efficient of the hydrogenotrophs, but require a source of sulfate; in the gut, the most prominent source of sulfate is sulfated glycans [80]. Although some of these glycans may be obtained from the diet, the most accessible source is mucin produced by the host [38]. Sulfatereducing bacteria obtain sulfate from these substrates via cross-feeding with microbes such as Bacteroides, which produce sulfatases $[80,81]$. Hydrogen sulfide is both directly toxic to IECs through inhibition of mitochondrial cytochrome $\mathrm{C}$ oxidase, and pro-inflammatory via activation of $\mathrm{T}$ helper 17 cells [82, 83]. Hydrogen sulfide can additionally directly act on disulfide bonds in mucin to further facilitate mucin degradation [84]. Elevated hydrogen sulfide concentrations and increased proportions of sulfatereducing bacteria are reported in IBD [85]. 


\section{Catabolism of amino acids}

The digestibility of proteins by the host is more variable than that of carbohydrates and fats, and is influenced by the previously mentioned factors of food processing, macronutrient ratios, and transit time [14, 18], in addition to its source (e.g., plant or animal), which also leads to different amino acid compositions available to the gut microbiota $[14,86]$. The extra steps of interconversion required for amino acid fermentation yield a large diversity of by-products. Protein catabolism in the gut generally has a negative connotation, as compounds that are toxic to the host can result from this process, including amines, phenols/indoles, and sulfurous compounds [12-14]. However, it is important to note that not all amino acids are fermented to toxic products as a result of gut microbial activity; in fact, the most abundant end products are SCFAs [13, 14]. Therefore, it may not be protein catabolism per se that negatively impacts the host, but instead specific metabolisms or overall increased protein fermentation activity. It is thus important to examine these subtleties. A microbe can exhibit one of two strategies for the initial step of amino acid catabolism, either deamination to produce a carboxylic acid plus ammonia or decarboxylation to produce an amine plus carbon dioxide [12]. Ammonia can inhibit mitochondrial oxygen consumption and decrease SCFA catabolism by IECs, which has led to the assumption that excess ammonia production can negatively impact the host [87-89]. However, the gut microbiota also rapidly assimilates ammonia into microbial amino acid biosynthetic processes [13], and host IECs can additionally control ammonia concentration through conversion to citrulline and glutamine, or through slow release into the bloodstream $[90,91]$. It is thus unclear how much protein catabolism is necessary to achieve toxic ammonia concentrations, and this may vary between hosts. This uncertainty, coupled with the multiple negative impacts amines can have on the host (discussed below), have led to speculation that deamination would improve host outcomes. Fortunately, deamination appears to be the more common strategy of amino acid catabolism by the gut microbiota, because high concentrations of SCFAs are produced from amino acid degradation via this pathway $[12,13]$. The next steps depend on the class of amino acid starting substrate, with most eventually resulting in tricarboxylic acid cycle intermediates, pyruvate, or coenzyme A-linked SCFA precursors [39, 75]. An exception would be the series of Stickland reactions exhibited by certain Clostridia, in which a coupled oxidation and reduction of two amino acids occurs as an alternative to using hydrogen ions as the electron acceptor [40, 41]. Phosphate is simultaneously added to the reduced amino acid in this case, and thus oxidative phosphorylation for the production of ATP can occur directly from the resultant acyl phosphate. In turn, branched-chain fatty acids (BCFAs), such as isovalerate and isobutyrate, can be produced as end-products. Additionally, some gut microbial species, mainly from the class Bacilli, also possess a specialized branched-chain keto acid dehydrogenase complex to yield energy from the oxidized forms of the branched-chain amino acids directly, which also leads to BCFA production [13, 75]. The major SCFA and BCFA products generated from degradation of each amino acid are presented in Table 2. BCFAs are often used as a biomarker of protein catabolism, with the promoted goal to reduce their concentration in order to improve health outcomes [14]. However, little is actually known about the impact of BCFAs on host health. In fact, preliminary work has shown that BCFAs are able to modulate glucose and lipid metabolism in the liver similarly to SCFAs [93], and isobutyrate can be used as a fuel source by IECs when butyrate is scarce [94]. What is undisputed, however, are the negative consequences of the pro-inflammatory, cytotoxic, and neuroactive compounds yielded from the sulfurcontaining, basic and aromatic amino acids.

\section{Sulfur-containing amino acids}

Catabolism of the sulfur-containing amino acids, cysteine and methionine, results in the production of hydrogen sulfide and methanethiol, respectively [13, 14], and a large number of taxonomically diverse bacterial species contain the requisite degradative enzymes within their genomes, including members of the Proteobacteria phylum, the Bacilli class, and the Clostridium and Bifidobacterium genera [13, 75]. Hydrogen sulfide can be methylated to methanethiol, which can be further methylated to dimethyl sulfide, and this methylation is thought to be part of the detoxification process due to the progressively less toxic nature of these compounds [95]. However, methanethiol may also be converted to hydrogen sulfide, then oxidized to sulfate, for detoxification; this sulfate can then be utilized by sulfate-reducing bacteria $[80,81,95]$. Indeed, this latter reaction has been observed in cecal tissue, and is part of the sulfur cycle of the gut [96]. The impact of hydrogen sulfide on host health has already been discussed, thus the focus will shift to the biogenic amines produced by basic amino acid fermentation and the phenol/indole compounds produced by aromatic amino acid fermentation.

\section{Basic amino acids}

A wide diversity of bacterial species within the gut microbiota can decarboxylate the basic amino acids, thus resulting in the formation of amine by-products shown in Additional file 1, including bifidobacteria, clostridia, lactobacilli, enterococci, streptococci, and members of the Enterobacteriaceae family [97]. The catabolism of arginine 
Table 2 Major products of amino acid fermentation by the human gut microbiota

\begin{tabular}{|c|c|c|}
\hline Amino acid & Amino acid class & Major products \\
\hline Aspartate & Acidic & Propionate \\
\hline Glutamate & Acidic & Acetate, Butyrate \\
\hline Alanine & Aliphatic & Acetate, Propionate, Butyrate \\
\hline Glycine & Aliphatic & $\frac{\text { Acetate }}{\text { Methylamine }}$ \\
\hline Isoleucine & Aliphatic & $\frac{\text { 2-Methylbutyrate }}{\text { to Valine }}$ or converted \\
\hline Leucine & Aliphatic & Isovalerate \\
\hline Proline & Aliphatic & Acetate \\
\hline Valine & Aliphatic & Isobutyrate \\
\hline Asparagine & Amidic & Converted to aspartate \\
\hline Glutamine & Amidic & Converted to glutamate \\
\hline Phenylalanine & Aromatic & $\begin{array}{l}\text { Phenolic SCFA } \\
\text { Phenylethylamine }\end{array}$ \\
\hline Tryptophan & Aromatic & $\begin{array}{l}\text { Indolic SCFA } \\
\text { Tryptamine }\end{array}$ \\
\hline Tyrosine & Aromatic & $\begin{array}{l}\text { 4-Hydroxyphenolic SCFA } \\
\text { Tyramine }\end{array}$ \\
\hline Arginine & Basic & $\begin{array}{l}\text { Converted to other amino } \\
\text { acids (mainly Ornithine) } \\
\text { Agmatine }\end{array}$ \\
\hline Histidine & Basic & $\begin{array}{l}\text { Acetate, Butyrate } \\
\text { Histamine }\end{array}$ \\
\hline Lysine & Basic & $\frac{\text { Acetate, }}{\text { Cadaverine }}$ \\
\hline Serine & Hydroxylic & Butyrate \\
\hline Threonine & Hydroxylic & Acetate, Propionate, Butyrate \\
\hline Cysteine & Sulfur-containing & Acetate, Butyrate, Hydrogen sulfide \\
\hline Methionine & Sulfur-containing & Propionate, Butyrate, Methanethiol \\
\hline
\end{tabular}

Listed are the compounds found to be above $1 \mathrm{mM}$ concentration in in vitro fermentation experiments conducted by Smith and Macfarlane [92], in

addition to the biogenic amines that can be produced by decarboxylation [12, 13]. Underlined are the products indicated as most abundant as reported in a review article by Fan et al. [12]

can produce agmatine by deamination, and/or putrescine, spermidine, and spermine as part of the polyamine synthesis pathway (Additional file 1). Agmatine inhibits the proliferation of IECs, which is thought to stem from its ability to reduce the synthesis and promote the degradation of other polyamines [98]. This effect may not be negative depending on the context; for example, the resultant decrease of fatty acid metabolism in tissues reduced both weight gain and the hormonal derangements associated with obesity in rats fed a high fat chow [99]. Agmatine also may be anti-inflammatory through inhibition of nitric oxide synthase [100], and is a candidate neurotransmitter, with agonism for $\alpha_{2}$-adenoceptors and imidazoline binding sites, while simultaneously blocking ligand-gated cation channels (NMDA class) [101]. The latter activity has therapeutic potential for remediating some forms of hyperalgesia and for its neuroprotectivity. Putrescine, on the other hand, is essential for the proliferation of IECs [102]. It is the precursor to spermidine/spermine, which are both able to relieve oxidative stress and promote cellular longevity through autophagy stimulation [103]. All three polyamines improve the integrity of the gut by increasing expression of tight junction proteins [104], promoting intestinal restitution [105] and increasing mucus secretion $[105,106]$. Finally, both putrescine and spermine are able to inhibit the production of proinflammatory cytokines, such as IL-1, IL-6, and TNF- $\alpha$ $[107,108]$. Therefore, any benefits of agmatine must be weighed against its consequent reduction of these polyamines; it may be effective in the treatment of certain conditions such as metabolic syndrome but could be detrimental in excess under normal conditions. Arginine can additionally be converted to glutamate, which can be deaminated to produce 4-aminobutryate (GABA). GABA is the major inhibitory neurotransmitter of the central nervous system, and alterations in the expression of its receptor have been linked to the pathogenesis of depression and anxiety [109]. Administration of lactobacilli and bifidobacteria that produce GABA to mice and rats has resulted in a decrease of depressive behaviors, a reduction of corticosterone induced stress and anxiety, and lessened visceral pain sensation [109-111]. GABA can additionally regulate the proliferation of $\mathrm{T}$ cells and thus has immunomodulatory properties [112]. Interestingly, chronic GI inflammation not only induces anxiety in mice, but depression and anxiety often present comorbidity with GI disorders, including irritable bowel syndrome (IBS) [109, 113].

The catabolism of histidine can produce histamine (Additional file 1). Histamine may be synonymous with its exertion of inflammation in allergic responses, but bacterially produced histamine has actually been shown to inhibit the production of the pro-inflammatory cytokines TNF- $\alpha$ in vivo [114], and IL-1, and IL-12 in vitro [115], while simultaneously preventing intestinal bacterial translocation. Histamine is also a neurotransmitter, modulating several processes such as wakefulness, motor control, dendritic cell activity, pain perception, and learning and memory [116]. Low levels of histamine are associated with Alzheimer's disease, convulsions, and seizures, and increasing its concentration has antinociceptive properties [117]. However, there is likely a range of suitable concentration, as high levels of histamine are associated with sleep disorders, Parkinson's disease, schizophrenia, and autism [116, 117].

The catabolism of lysine can produce cadaverine (Additional file 1). Cadaverine is a poorly studied metabolite; it can be toxic, but only in high amounts $[13,97]$. Cadaverine has, however, been shown to potentiate histamine toxicity [118] and higher concentrations of cadaverine are associated with ulcerative colitis (UC) [119]. 


\section{Aromatic amino acids}

Aromatic amino acid degradation can yield a wide diversity of indolic and phenolic compounds that can act as toxins or neurotransmitters as shown in Additional file 2. The catabolism of tryptophan can produce tryptamine and indoles (Additional file 2). Tryptamine is a neurotransmitter that plays a role in regulating intestinal motility and immune function [120]. Particularly, it is able to interact with both indoleamine 2,3-dioxygenase and the aryl hydrocarbon receptor to heighten immune surveillance, and dampen the expression of pro-inflammatory cytokines, respectively $[121,122]$. A lack of these activities has therefore been implicated in the pathology of IBD; although, it should be noted that most tryptophan metabolites can interact with these receptors, thus it is not tryptamine-specific [13, 120, 122]. Tryptamine can also both potentiate the inhibitory response of cells to serotonin and induce its release from enteroendocrine cells $[120,123]$. Serotonin is a neurotransmitter involved in many processes including mood, appetite, hemostasis, immunity, and bone development $[13,124]$. Its dysregulation is thus reported in many disorders, including IBD [125], IBS [126], cardiovascular disease [127], and osteoporosis [128]. Tryptophan decarboxylation is a rare activity among species of the gut microbiota, but certain Firmicutes have been found to be capable of it, including the IBDassociated species, Ruminococcus gnavus [129, 130]. Indole, on the other hand, is a major bacterial metabolite of tryptophan, produced by many species of Bacteroides and Enterobacteriaceae [120]. It plays an important role in host defense, by interacting with the pregnane $\mathrm{X}$ receptor and the aryl hydrocarbon receptor [120]. This activity fortifies the intestinal barrier by increasing tight junction protein expression and downregulates the expression of proinflammatory cytokines [120, 131]. It also induces glucagon like peptide-1 (an incretin) secretion by enteroendocrine cells, inhibiting gastric secretion and motility, to promote satiety $[132,133]$. Indole is additionally a signaling molecule for bacteria, influencing motility, biofilm formation, antibiotic resistance, and virulence, and shown to inhibit the colonization capabilities of pathogens such as Salmonella enterica [134]. However, indole overproduction can increase its export to the liver, where it is sulfated to indoxyl sulfate, a uremic toxin associated with chronic kidney disease [135]. Further, its effects as a signaling molecule for both enteroendocrine cells and bacteria are dose dependent, with high concentrations rendering it ineffective $[120,132,134]$. Other indole metabolites are additionally able to interact with the pregnane $\mathrm{X}$ receptor and/or aryl hydrocarbon receptor in a similar fashion, thus benefiting the host, but are less well studied [120].

The catabolism of tyrosine can produce tyramine, phenols, and p-coumarate (Additional file 2). Tyramine is a neurotransmitter that can be produced by certain gut bacteria via decarboxylation, including Enterococcus and Enterobacteriaceae [97]. It is infamous for causing the 'cheese reaction' hypertensive crisis in individuals taking monoamine inhibitor class drugs, although it can additionally cause migraines and hypertension in sensitive individuals or a mild rise in blood pressure when consumed in excess by the general populace [136]. Tyramine facilitates the release of norepinephrine that induces peripheral vasoconstriction, elevates blood glucose levels, and increases cardiac output and respiration [137]. It has also been shown to increase the synthesis of serotonin by enteroendocrine cells in the gut, elevating its release into circulation [124]. Phenol and p-cresol are phenolic metabolites that have been shown to both decrease the integrity of the gut epithelium and the viability of IECs [138, 139], and can be produced by many gut bacterial species, such as members of the Enterobacteriaceae and Clostridium clusters I, XI, and XIVa [140]. P-cresol in particular is genotoxic, elevates the production of superoxide, and inhibits proliferation of IECs [141]. P-cresol may additionally be sulfated to cresyl sulfate in the gut or liver, which has been found to suppress the $\mathrm{T}$ helper 1-mediated immune response in mice [142], and, interestingly, phenolic sulfation was found to be impaired in the gut mucosa of UC patients [143]. Indeed, the colonic damage induced by unconjugated phenols is similar to that observed in IBD [138]. Cresyl sulfate is also associated with chronic kidney disease, however, as it can damage renal tubular cells through induction of oxidative stress [144]. This compound is also particularly elevated in the urine of autistic patients, but a causative link in this case has not been elucidated [145].

The catabolism of phenylalanine can produce phenylethylamine and trans-cinnamic acid (Additional file 2). Unlike tyrosine and tryptophan, little is known about these phenylalanine-derived metabolites. Phenylethylamine is a neurotransmitter that functions as an 'endogenous amphetamine' yielded from decarboxylation [136]. Through facilitating the release of catecholamine and serotonin, phenylethylamine in turn elevates mood, energy, and attention [146]. However, it has been reported that ingesting phenylethylamine can induce headache, dizziness, and discomfort in individuals with a reduced ability to convert it to phenylacetate, suggesting excessive amounts have negative consequences [136]. In terms of its production in the gut, phenylethylamine has thus been positively associated with Crohn's disease and negatively correlated with Faecalibacterium prausnitzii in one study [147]. The conversion of phenylalanine to trans-cinnamate and tyrosine to pcoumaric acid results in increased phenylpropionate and 4hydroxyphenylpropionate concentrations, which in turn produce urinary metabolites associated with the 'chlorogenic acid' phenotype in rats, as suggested by Clayton [148]. These metabolic pathways were found to so far specifically occur within species of Clostridium and 
Peptostreptococcus, respectively $[149,150]$. The chlorogenic acid phenotype is associated with both autism and schizophrenia, suggesting a role of altered aromatic amino acid metabolism in these disorders [148, 151, 152]. However, further research is still needed, as there remains no mechanistic explanation of these metabolites toward disease development. Further, both trans-cinnamic acid and pcoumaric acid are negatively associated with cardiovascular disease $[153,154]$. P-coumaric acid, in particular, is a common phenolic compound derived from plant matter that has anti-inflammatory properties, and has been demonstrated to prevent platelet aggregation [155]. Thus, these metabolites may simply be an indicator of altered microbial metabolism in general, when found in excess.

\section{Catabolism of lipids}

A very small proportion of total dietary fat reaches the colon $(<5 \%)[16,156]$. Microorganisms in the gut are known to possess lipases, which can degrade triglycerides and phospholipids into their polar head groups and free lipids [16, 157]. Triglycerides represent $95 \%$ of total dietary fat, whereas phospholipids, mostly in the form of phosphotidylcholine, constitute a minor portion, but are also derived endogenously from bile acids [158]. Certain bacteria inhabiting the GI tract, including species of lactobacilli, enterococci, clostridia, and Proteobacteria, can utilize the backbone of triglycerides as an electron sink, reducing glycerol to 1,3-propanediol [159]. 3-Hydroxypropanal (reuterin) is an intermediate of this process that has been reported to accumulate extracellularly in cultures of Lactobacillus and Enterococcus spp. [160]. Reuterin has antimicrobial properties acting against pathogens and commensals alike [161], but it can also be spontaneously dehydrated to acrolein [71]. Acrolein is a highly reactive genotoxin, with an equivalent mutagenic potency to formaldehyde, raising concerns about this metabolic process $[71,159]$. Meanwhile, choline can additionally be metabolized to trimethylamine by species of the gut microbiota, particularly Clostridia (especially members of Clostridium cluster XIVa and Eubacterium spp.) and Proteobacteria $[162,163]$. Trimethylamine is oxidized in the liver to trimethylamine $\mathrm{N}$-oxide $[163,164]$, which exacerbates atherosclerosis by promoting the formation of foam cells (lipidladen macrophages) [164] and altering cholesterol transport [165]. High levels of serum trimethylamine $\mathrm{N}$-oxide are thus associated with cardiovascular disease [166] and atherosclerosis [167]. However, it should be noted that active research in these areas is in its early stages, and thus the link between the gut microbiota-mediated lipid head group metabolism and health consequences is still unclear. For example, a study on the metabolism of glycerol by fecal microbial communities found that only a subset could reduce it to 1,3-propanediol, and the authors did not detect any reuterin [159]. Further, some members of the gut microbiota (e.g., methylotrophs) can breakdown trimethylamine to dimethylamine, so the actual amount of trimethylamine that is available for transportation to the liver can be diverted, and this is likely to be influenced by interindividual variability in the composition of the gut microbiota [168].

In contrast to the polar head groups, microorganisms are not thought to have the ability to catabolize free lipids in the anaerobic environment of the gut [169]. However, free lipids have antimicrobial properties [169, $170]$ and can directly interact with host pattern recognition receptors. Particularly, saturated fatty acids are TLR4 agonists that promote inflammation [171], whereas omega- 3 unsaturated fatty acids are TLR4 antagonists that prevent inflammation [172]. Interestingly, chronic inflammation co-occurring with obesity has been well described [173], and could be a result of the aforementioned pro-inflammatory properties of free lipids, the lack of anti-inflammatory SCFAs produced from carbohydrate fermentation (high-fat diets tend to be low in carbohydrates), or a combination of both. High-fat diets do have a reported impact on the composition of the gut microbiota, yet it is unclear whether it is the increased fat content per se or the relative decrease in carbohydrates, which often accompanies these diets, that is the chief influencer [16, 169]. Indeed, Morales et al. observed that a high-fat diet including fiber supplementation induces inflammation without altering the composition of the gut microbiota [16]. Regardless, the gut microbiota is required for the development of obesity, as shown in GF mice experiments, because of the ability of SCFAs to alter energy balance as previously discussed [174].

\section{Effect on endogenous substrate utilization}

Metabolism of exogenous substrates greatly affects the use of endogenous substrates by the gut microbiota. Dietary fiber reduces the degradation of mucin, and the utilization of mucin is thought to cycle daily depending on the availability of food sources $[175,176]$. Mucin is a sulfated glycoprotein [38], thus the same concepts of carbohydrate and protein degradation from dietary sources discussed above apply. However, it should be noted that mucin turnover by the gut microbiota is a naturally occurring process, and only when it occurs in elevated amounts does it have negative connotations. For example, Akkermansia muciniphila is a mucinutilizing specialist that is depleted in the GI tract of IBD [177] and metabolic syndrome [178] patients. A. muciniphila has a demonstrated ability to cross-talk with host cells, promoting an increase in concentration of glucagon-like peptides, 2-arabinoglycerol, and antimicrobial peptides that improve barrier function, reduce inflammation, and induce proliferation of IECs [179]. 
Through this communication, A. muciniphila also, paradoxically, restored the thickness of the mucin layer in obese mice. Dietary fat intake can also alter the profile of bile acids. Dairy-derived saturated lipids increase the relative amount of taurine-conjugation, and this sulfurcontaining compound leads to the expansion of sulfatereducing bacteria in the gut [180]. Bile acid turnover is, however, a naturally occurring process, which modulates bile acid reabsorption, inflammation, triglyceride control, and glucose homeostasis from IEC signaling [181].

\section{Conclusions}

The critical contributions of the gut microbiota toward human digestion have just begun to be elucidated. Particularly, more recent research is revealing how the impacts of microbial metabolism extend beyond the GI tract, denoting the so-called gut-brain (e.g., biogenic amines acting as neurotransmitters) [182], gut-liver (e.g., alcohols) [183], gut-kidney (e.g., uremic toxins such as cresyl sulfate) [135], and gut-heart (e.g., trimethylamine) [184] axes. The primary focus to date has been on the SCFAs derived mainly from complex carbohydrates, and crucial knowledge gaps still remain in this area, specifically on how the SCFAs modulate glucose metabolism and fat deposition upon reaching the liver. However, the degradation of proteins and fats are comparatively less well understood. Due to both the diversity of metabolites that can be yielded and the complexity of microbial pathways, which can act as a self-regulating system that removes toxic byproducts, it is not merely a matter of such processes effecting health positively or negatively, but rather how they are balanced. Further, the presentation of these substrates to the gut microbiota, as influenced by the relatively understudied host digestive processes occurring in the small intestine, is equally important. Future work could therefore aim to determine which of these pathways are upregulated and downregulated in disease states, such as autism and depression (gut-brain), NAFLD (gut-liver), chronic kidney disease (gut-kidney), and cardiovascular disease (gut-heart). Further, a combination of human- and culture- (in vitro and in vivo) based studies could resolve the spectrum of protein and fat degradation present among healthy individuals, in order to further our understanding of nutrient cycling in gut microbial ecosystems, and thus gain a necessary perspective for improving wellness.

\section{Additional files}

Additional file 1: Pathways of basic amino acid fermentation by the human gut microbiome. Pathways have been simplifed to show major endproducts. Where 'SCFA' is listed, either acetate, propionate or butyrate can result from catabolism of the substrate. (PDF $181 \mathrm{~kb}$ )
Additional file 2: Pathways of aromatic amino acid fermentation by the human gut microbiome. Pathways have been simplified to show major end-products. Where 'SCFA' is listed, either acetate, propionate or butyrate can result from catabolism of the substrate. (PDF $174 \mathrm{~kb}$ )

\section{Abbreviations}

APC: Antigen presenting cell; BCFA: Branched-chain fatty acid; GABA: 4Aminobutryate; GI: Gastrointestinal; IBD: Inflammatory bowel disease; IBS: Irritable bowel syndrome; IEC: Intestinal epithelial cell; NAFLD: Nonalcoholic fatty liver disease; SCFA: Short-chain fatty acid; TLR: Toll-like receptor; UC: Ulcerative colitis

\section{Acknowledgements}

Not applicable.

\section{Funding}

We would like to acknowledge the National Science and Research Council of Canada scholarship and Ontario Ministry of Training, Colleges and Universities scholarship to KO for providing funding.

Availability of data and materials

Not applicable.

Authors' contributions

$\mathrm{KO}$ researched and wrote the manuscript. EA-V oversaw editing of the final version of the manuscript. All authors approved the final manuscript.

Ethics approval and consent to participate

Not applicable.

Consent for publication

Not applicable.

\section{Competing interests}

EA-V is the co-founder and CSO of NuBiyota LLC, a company which is working to commercialize human gut-derived microbial communities for use in medical indications.

\section{Publisher's Note}

Springer Nature remains neutral with regard to jurisdictional claims in published maps and institutional affiliations.

Received: 31 March 2019 Accepted: 28 May 2019

Published online: 13 June 2019

\section{References}

1. Thursby E, Juge N. Introduction to the human gut microbiota. Biochem J. 2017:474:1823-36

2. Li J, Jia H, Cai X, Zhong H, Feng Q, Sunagawa S, et al. An integrated catalog of reference genes in the human gut microbiome. Nat Biotechnol. 2014:32:834-41.

3. Turnbaugh PJ, Ley RE, Hamady M, Fraser-Liggett C, Knight R, Gordon Jl. The human microbiome project: exploring the microbial part of ourselves in a changing world. Nature. 2007;449:804-10.

4. Human Microbiome Project Consortium. Structure, function and diversity of the healthy human microbiome. Nature. 2012;486:207-14.

5. Belkaid $Y$, Hand $T$. Role of the microbiota in immunity and inflammation. Cell. 2014;157:121-41.

6. Spiljar M, Merkler D, Trajkovski M. The immune system bridges the gut microbiota with systemic energy homeostasis: focus on TLRs, mucosal barrier, and SCFAs. Front Immunol. 2017;8:1353.

7. Hillman ET, Lu H, Yao T, Nakatsu CH. Microbial ecology along the gastrointestinal tract. Microbes Environ. 2017;32:300-13.

8. Martinez-Guryn K, Hubert N, Frazier K, Urlass S, Musch MW, Ojeda P, et al. Small intestine microbiota regulate host digestive and absorptive adaptive responses to dietary lipids. Cell Host Microbe. 2018;23:458-69. e5

9. Sommer F, Anderson JM, Bharti R, Raes J, Rosenstiel P. The resilience of the intestinal microbiota influences health and disease. Nat Rev Microbiol. 2017; 15:630-8. 
10. Theriot CM, Young VB. Interactions between the gastrointestinal microbiome and Clostridium difficile. Annu Rev Microbiol. 2015;69:445-61.

11. Stecher B, Hardt W-D. Mechanisms controlling pathogen colonization of the gut. Curr Opin Microbiol. 2011;14:82-91.

12. Fan P, Li L, Rezaei A, Eslamfam S, Che D, Ma X. Metabolites of dietary protein and peptides by intestinal microbes and their impacts on gut. Curr Protein Pept Sci. 2015;16:646-54.

13. Portune KJ, Beaumont M, Davila A-M, Tomé D, Blachier F, Sanz Y. Gut microbiota role in dietary protein metabolism and health-related outcomes: the two sides of the coin. Trends Food Sci Technol. 2016;57:213-32.

14. Yao CK, Muir JG, Gibson PR. Review article: insights into colonic protein fermentation, its modulation and potential health implications. Aliment Pharmacol Ther. 2016:43:181-96.

15. Krajmalnik-Brown R, Ihan Z-E, Kang D-W, DiBaise JK. Effects of gut microbes on nutrient absorption and energy regulation. Nutr Clin Pract Off Publ Am Soc Parenter Enter Nutr. 2012;27:201-14.

16. Morales P, Fujio S, Navarrete P, Ugalde JA, Magne F, Carrasco-Pozo C, et al. Impact of dietary lipids on colonic function and microbiota: an experimental approach involving orlistat-induced fat malabsorption in human volunteers. Clin Transl Gastroenterol. 2016;7:e161.

17. Wong JMW, Jenkins DJA. Carbohydrate digestibility and metabolic effects. J Nutr. 2007;137:2539S-46S.

18. Roager HM, Hansen LBS, Bahl Ml, Frandsen HL, Carvalho V, Gøbel RJ, et al. Colonic transit time is related to bacterial metabolism and mucosal turnover in the gut. Nat Microbiol. 2016;1:16093.

19. Degen LP, Phillips SF. Variability of gastrointestinal transit in healthy women and men. Gut. 1996:39:299-305.

20. Biesalski HK. Nutrition meets the microbiome: micronutrients and the microbiota. Ann N Y Acad Sci. 2016;1372:53-64.

21. Ozdal T, Sela DA, Xiao J, Boyacioglu D, Chen F, Capanoglu E. The reciprocal interactions between polyphenols and gut microbiota and effects on bioaccessibility. Nutrients. 2016:8:78

22. Bhattacharya T, Ghosh TS, Mande SS. Global profiling of carbohydrate active enzymes in human gut microbiome. PLoS One. 2015;10:e0142038.

23. Xu J, Bjursell MK, Himrod J, Deng S, Carmichael LK, Chiang HC, et al. A genomic view of the human-Bacteroides thetaiotaomicron symbiosis. Science. 2003;299:2074-6.

24. Singh RK, Chang H-W, Yan D, Lee KM, Ucmak D, Wong K, et al. Influence of diet on the gut microbiome and implications for human health. J Transl Med. 2017:15:73

25. Wolfe AJ. Glycolysis for the microbiome generation. Microbiol Spectr. 2015;3 https://doi.org/10.1128/microbiolspec.MBP-0014-2014.

26. Vergnolle N. Protease inhibition as new therapeutic strategy for GI diseases. Gut. 2016;65:1215-24.

27. Lin R, Liu W, Piao M, Zhu H. A review of the relationship between the gut microbiota and amino acid metabolism. Amino Acids. 2017;49:2083-90.

28. Smith EA, Macfarlane GT. Enumeration of amino acid fermenting bacteria in the human large intestine: effects of $\mathrm{pH}$ and starch on peptide metabolism and dissimilation of amino acids. FEMS Microbiol Ecol. 1998;25:355-68.

29. Geboes KP, De Hertogh G, De Preter V, Luypaerts A, Bammens B, Evenepoel $P$, et al. The influence of inulin on the absorption of nitrogen and the production of metabolites of protein fermentation in the colon. $\mathrm{Br} J$ Nutr. 2006:96:1078-86.

30. Donohoe DR, Garge N, Zhang X, Sun W, O'Connell TM, Bunger MK, et al. The microbiome and butyrate regulate energy metabolism and autophagy in the mammalian colon. Cell Metab. 2011;13:517-26.

31. Falony $G$, Joossens $M$, Vieira-Silva S, Wang J, Darzi Y, Faust $K$, et al. Populationlevel analysis of gut microbiome variation. Science. 2016;352:560-4.

32. Lloyd-Price J, Abu-Ali G, Huttenhower C. The healthy human microbiome. Genome Med. 2016;8:51.

33. Koh A, De Vadder F, Kovatcheva-Datchary P, Bäckhed F. From dietary fiber to host physiology: short-chain fatty acids as key bacterial metabolites. Cell. 2016;165:1332-45.

34. Macfarlane GT, Macfarlane S. Bacteria, colonic fermentation, and gastrointestinal health. J AOAC Int. 2012;95:50-60.

35. Mountfort DO, Grant WD, Clarke R, Asher RA. Eubacterium callanderi sp. nov. that demethoxylates O-methoxylated aromatic acids to volatile fatty acids. Int J Syst Evol Microbiol. 1988;38:254-8.

36. McDonald JAK, Mullish BH, Pechlivanis A, Liu Z, Brignardello J, Kao D, et al. Inhibiting growth of Clostridioides difficile by restoring Valerate, produced by the intestinal microbiota. Gastroenterology. 2018;155:1495-507. e15
37. Wolf PG, Biswas A, Morales SE, Greening C, Gaskins HR. H2 metabolism is widespread and diverse among human colonic microbes. Gut Microbes. 2016;7:235-45

38. Tailford LE, Crost EH, Kavanaugh D, Juge N. Mucin glycan foraging in the human gut microbiome. Front Genet. 2015;6:81.

39. Louis P, Flint HJ. Formation of propionate and butyrate by the human colonic microbiota. Environ Microbiol. 2017;19:29-41.

40. Fischbach MA, Sonnenburg JL. Eating for two: how metabolism establishes interspecies interactions in the gut. Cell Host Microbe. 2011;10:336-47.

41. de Vladar HP. Amino acid fermentation at the origin of the genetic code. Biol Direct. 2012;7:6

42. Lopetuso LR, Scaldaferri F, Petito V, Gasbarrini A. Commensal clostridia: leading players in the maintenance of gut homeostasis. Gut Pathog. 2013;5:23.

43. Pokusaeva K, Fitzgerald GF, van Sinderen D. Carbohydrate metabolism in Bifidobacteria. Genes Nutr. 2011:6:285-306.

44. Jumas-Bilak E, Carlier J-P, Jean-Pierre H, Teyssier C, Gay B, Campos J, et al. Veillonella montpellierensis sp. nov., a novel, anaerobic, gram-negative coccus isolated from human clinical samples. Int J Syst Evol Microbiol. 2004;54: 1311-6.

45. Paixão L, Oliveira J, Veríssimo A, Vinga S, Lourenço EC, Ventura MR, et al. Host glycan sugar-specific pathways in Streptococcus pneumonia: galactose as a key sugar in colonisation and infection. PLoS One. 2015;10:e0121042.

46. Duncan SH, Hold GL, Harmsen HJM, Stewart CS, Flint HJ. Growth requirements and fermentation products of Fusobacterium prausnitzii, and a proposal to reclassify it as Faecalibacterium prausnitzii gen. Nov., comb. nov. Int J Syst Evol Microbiol. 2002;52:2141-6.

47. Charalampopoulos D, Pandiella SS, Webb C. Growth studies of potentially probiotic lactic acid bacteria in cereal-based substrates. J Appl Microbiol. 2002;92:851-9.

48. Taras D, Simmering R, Collins MD, Lawson PA, Blaut M. Reclassification of Eubacterium formicigenerans Holdeman and Moore 1974 as Dorea formicigenerans gen. nov., comb. nov., and description of Dorea longicatena sp. nov., isolated from human faeces. Int J Syst Evol Microbiol. 2002;52:423-8.

49. Holdeman LV, Moore WEC. New genus, Coprococcus, twelve new species, and emended descriptions of four previously described species of bacteria from human feces. Int J Syst Evol Microbiol. 1974;24:260-77.

50. Liu C, Finegold SM, Song Y, Lawson PA. Reclassification of Clostridium coccoides, Ruminococcus hansenii, Ruminococcus hydrogenotrophicus, Ruminococcus luti, Ruminococcus productus and Ruminococcus schinkii as Blautia coccoides gen. Nov., comb. nov., Blautia hansenii comb. nov., Blautia hydrogenotrophica comb. nov., Blautia luti comb. nov., Blautia producta comb. nov., Blautia schinkii comb. nov. and description of Blautia wexlerae sp. nov., isolated from human faeces. Int J Syst Evol Microbiol. 2008;58:1896-902.

51. Roh H, Ko H-J, Kim D, Choi DG, Park S, Kim S, et al. Complete genome sequence of a carbon monoxide-utilizing Acetogen, Eubacterium limosum KIST612. J Bacteriol. 2011:193:307-8.

52. Polansky O, Sekelova Z, Faldynova M, Sebkova A, Sisak F, Rychlik I. Important metabolic pathways and biological processes expressed by chicken cecal microbiota. Appl Environ Microbiol. 2016;82:1569-76.

53. Sakamoto M, Benno Y. Reclassification of Bacteroides distasonis, Bacteroides goldsteinii and Bacteroides merdae as Parabacteroides distasonis gen. nov., comb. nov., Parabacteroides goldsteinii comb. nov. and Parabacteroides merdae comb. nov. Int J Syst Evol Microbiol. 2006;56:1599-605.

54. Rautio M, Eerola E, Väisänen-Tunkelrott M-L, Molitoris D, Lawson P, Collins MD, et al. Reclassification of Bacteroides putredinis (Weinberg et al., 1937) in a new genus Alistipes gen. nov., as Alistipes putredinis comb. nov., and description of Alistipes finegoldii sp. nov., from human sources. Syst Appl Microbiol. 2003;26:182-8.

55. Kaneuchi C, Miyazato T, Shinjo T, Mitsuoka T. Taxonomic study of helically coiled, Sporeforming anaerobes isolated from the intestines of humans and other animals: Clostridium cocleatum sp. nov. and Clostridium spiroforme sp. nov. Int J Syst Evol Microbiol. 1979;29:1-12.

56. Yutin N, Galperin MY. A genomic update on clostridial phylogeny: gramnegative spore-formers and other misplaced clostridia. Environ Microbiol. 2013:15:2631-41.

57. Liang K, Shen CR. Selection of an endogenous 2,3-butanediol pathway in Escherichia coli by fermentative redox balance. Metab Eng. 2017;39:181-91.

58. Chassard C, Delmas E, Robert C, Lawson PA. Bernalier-Donadille a. Ruminococcus champanellensis sp. nov, a cellulose-degrading bacterium from human gut microbiota. Int J Syst Evol Microbiol. 2012;62:138-43.

59. Mashima I, Liao Y-C, Miyakawa H, Theodorea CF, Thawboon B, Thaweboon $S$, et al. Veillonella infantium sp. nov., an anaerobic, gram-stain-negative 
coccus isolated from tongue biofilm of a Thai child. Int J Syst Evol Microbiol. 2018;68:1101-6.

60. Elshaghabee FMF, Bockelmann W, Meske D, de Vrese M, Walte H-G, Schrezenmeir J, et al. Ethanol production by selected intestinal microorganisms and lactic acid bacteria growing under different nutritional conditions. Front Microbiol. 2016;7:47.

61. Kelly WJ, Henderson G, Pacheco DM, Li D, Reilly K, Naylor GE, et al. The complete genome sequence of Eubacterium limosum SA11, a metabolically versatile rumen acetogen. Stand Genomic Sci. 2016;11:26.

62. Morrison DJ, Preston T. Formation of short chain fatty acids by the gut microbiota and their impact on human metabolism. Gut Microbes. 2016;7:189-200.

63. den Besten G, van Eunen K, Groen AK, Venema K, Reijngoud D-J, Bakker BM. The role of short-chain fatty acids in the interplay between diet, gut microbiota, and host energy metabolism. J Lipid Res. 2013;54:2325-40.

64. Ríos-Covián D, Ruas-Madiedo P, Margolles A, Gueimonde M. de los ReyesGavilán CG, Salazar N. intestinal short chain fatty acids and their link with diet and human health. Front Microbiol. 2016;7:185.

65. Lee W-J, Hase K. Gut microbiota-generated metabolites in animal health and disease. Nat Chem Biol. 2014;10:416-24.

66. Nishina PM, Freedland RA. Effects of propionate on lipid biosynthesis in isolated rat hepatocytes. J Nutr. 1990;120:668-73.

67. Chambers ES, Viardot A, Psichas A, Morrison DJ, Murphy KG, Zac-Varghese SEK, et al. Effects of targeted delivery of propionate to the human colon on appetite regulation, body weight maintenance and adiposity in overweight adults. Gut. 2015;64:1744-54.

68. Layden BT, Yalamanchi SK, Wolever TM, Dunaif A, Lowe WL. Negative association of acetate with visceral adipose tissue and insulin levels. Diabetes Metab Syndr Obes Targets Ther. 2012;5:49-55.

69. Dorokhov YL, Shindyapina AV, Sheshukova EV, Komarova TV. Metabolic methanol: molecular pathways and physiological roles. Physiol Rev. 2015;95:603-44

70. Gkolfakis P, Dimitriadis G, Triantafyllou K. Gut microbiota and non-alcoholic fatty liver disease. Hepatobiliary Pancreat Dis Int. 2015;14:572-81.

71. O'Brien PJ, Siraki AG, Shangari N. Aldehyde sources, metabolism, molecular toxicity mechanisms, and possible effects on human health. Crit Rev Toxicol. 2005;35:609-62.

72. Zhu L, Baker SS, Gill C, Liu W, Alkhouri R, Baker RD, et al. Characterization of gut microbiomes in nonalcoholic steatohepatitis (NASH) patients: a connection between endogenous alcohol and NASH. Hepatology. 2013;57:601-9.

73. Lane ER, Zisman TL, Suskind DL. The microbiota in inflammatory bowel disease: current and therapeutic insights. J Inflamm Res. 2017;10:63-73.

74. Principi M, lannone A, Losurdo G, Mangia M, Shahini E, Albano F, et al. Nonalcoholic fatty liver disease in inflammatory bowel disease: prevalence and risk factors. Inflamm Bowel Dis. 2018;24:1589-96.

75. Kanehisa M, Goto S. KEGG: Kyoto encyclopedia of genes and genomes. Nucleic Acids Res. 2000;28:27-30.

76. Hinnebusch BF, Meng S, Wu JT, Archer SY, Hodin RA. The effects of shortchain fatty acids on human colon cancer cell phenotype are associated with histone hyperacetylation. J Nutr. 2002;132:1012-7.

77. Miceli JF, Torres Cl, Krajmalnik-Brown R. Shifting the balance of fermentation products between hydrogen and volatile fatty acids: microbial community structure and function. FEMS Microbiol Ecol. 2016;92:fiw195.

78. Mack I, Cuntz U, Grämer C, Niedermaier S, Pohl C, Schwiertz A, et al. Weight gain in anorexia nervosa does not ameliorate the faecal microbiota, branched chain fatty acid profiles, and gastrointestinal complaints. Sci Rep. 2016;6:26752.

79. Armougom F, Henry M, Vialettes B, Raccah D, Raoult D. Monitoring bacterial Community of Human gut Microbiota Reveals an increase in lactobacillus in obese patients and methanogens in anorexic patients. PLoS One. 2009:4:e7125.

80. Rey FE, Gonzalez MD, Cheng J, Wu M, Ahern PP, Gordon Jl. Metabolic niche of a prominent sulfate-reducing human gut bacterium. Proc Natl Acad Sci U S A. 2013;110:13582-7.

81. Benjdia A, Martens EC, Gordon Jl, Berteau O. Sulfatases and a radical Sadenosyl-L-methionine (AdoMet) enzyme are key for mucosal foraging and fitness of the prominent human gut symbiont, Bacteroides thetaiotaomicron. J Biol Chem. 2011;286:25973-82.

82. Nicholls P, Kim JK. Sulphide as an inhibitor and electron donor for the cytochrome c oxidase system. Can J Biochem. 1982;60:613-23.

83. Figliuolo VR, dos Santos LM, Abalo A, Nanini H, Santos A, Brittes NM, et al. Sulfate-reducing bacteria stimulate gut immune responses and contribute to inflammation in experimental colitis. Life Sci. 2017;189:29-38.
84. ljssennagger N, Belzer C, Hooiveld GJ, Dekker J, van Mil SWC, Müller M, et al. Gut microbiota facilitates dietary heme-induced epithelial hyperproliferation by opening the mucus barrier in colon. Proc Natl Acad Sci U S A. 2015;112:10038-43.

85. Ijssennagger $\mathrm{N}$, van der MR, van MSWC. Sulfide as a mucus barrier-breaker in inflammatory bowel disease? Trends Mol Med. 2016;22:190-9.

86. Madsen L, Myrmel LS, Fjære E, Liaset B, Kristiansen K. Links between dietary protein sources, the gut microbiota, and obesity. Front Physiol. 2017;8:1047.

87. Andriamihaja M, Davila A-M, Eklou-Lawson M, Petit N, Delpal S, Allek F, et al. Colon luminal content and epithelial cell morphology are markedly modified in rats fed with a high-protein diet. Am J Physiol-Gastrointest Liver Physiol. 2010;299:G1030-7.

88. Hughes R, Kurth MJ, McGilligan V, McGlynn H, Rowland I. Effect of colonic bacterial metabolites on Caco-2 cell paracellular permeability in vitro. Nutr Cancer. 2008;60:259-66.

89. Cremin JD, Fitch MD, Fleming SE. Glucose alleviates ammonia-induced inhibition of short-chain fatty acid metabolism in rat colonic epithelial cells. Am J Physiol-Gastrointest Liver Physiol. 2003;285:G105-14.

90. Eklou-Lawson M, Bernard F, Neveux N, Chaumontet C, Bos C, Davila-Gay A$M$, et al. Colonic luminal ammonia and portal blood I-glutamine and Iarginine concentrations: a possible link between colon mucosa and liver ureagenesis. Amino Acids. 2009;37:751-60.

91. Mouillé B, Robert V, Blachier F. Adaptative increase of ornithine production and decrease of ammonia metabolism in rat colonocytes after hyperproteic diet ingestion. Am J Physiol-Gastrointest Liver Physiol. 2004;287:G344-51.

92. Smith EA, Macfarlane GT. Dissimilatory amino acid metabolism in human colonic bacteria. Anaerobe. 1997;3:327-37.

93. Heimann E, Nyman M, Pålbrink A-K, Lindkvist-Petersson K, Degerman E. Branched short-chain fatty acids modulate glucose and lipid metabolism in primary adipocytes. Adipocyte. 2016;5:359-68.

94. Jaskiewicz J, Zhao Y, Hawes JW, Shimomura Y, Crabb DW, Harris RA. Catabolism of isobutyrate by colonocytes. Arch Biochem Biophys. 1996;327:265-70.

95. Tangerman A. Measurement and biological significance of the volatile sulfur compounds hydrogen sulfide, methanethiol and dimethyl sulfide in various biological matrices. J Chromatogr B. 2009;877:3366-77.

96. Furne J, Springfield J, Koenig T, DeMaster E, Levitt MD. Oxidation of hydrogen sulfide and methanethiol to thiosulfate by rat tissues: a specialized function of the colonic mucosa. Biochem Pharmacol. 2001; 62:255-9.

97. Pugin B, Barcik W, Westermann P, Heider A, Wawrzyniak M, Hellings $P$, et al. A wide diversity of bacteria from the human gut produces and degrades biogenic amines. Microb Ecol Health Dis. 2017;28:1353881.

98. Mayeur C, Veuillet G, Michaud M, Raul F, Blottière HM, Blachier F. Effects of agmatine accumulation in human colon carcinoma cells on polyamine metabolism, DNA synthesis and the cell cycle. Biochim Biophys Acta BBA Mol Cell Res. 2005;1745:111-23.

99. Nissim I, Horyn O, Daikhin Y, Chen P, Li C, Wehrli SL, et al. The molecular and metabolic influence of long term agmatine consumption. J Biol Chem. 2014;289:9710-29.

100. Auguet M, Viossat I, Marin JG, Chabrier PE. Selective inhibition of inducible nitric oxide synthase by agmatine. Jpn J Pharmacol. 1995;69:285-7.

101. Reis DJ, Regunathan $\mathrm{S}$. Is agmatine a novel neurotransmitter in brain? Trends Pharmacol Sci. 2000;21:187-93.

102. Mouillé B, Delpal S, Mayeur C, Blachier F. Inhibition of human colon carcinoma cell growth by ammonia: a non-cytotoxic process associated with polyamine synthesis reduction. Biochim Biophys Acta BBA - Gen Subj. 2003;1624:88-97.

103. Eisenberg T, Knauer H, Schauer A, Büttner S, Ruckenstuhl C, CarmonaGutierrez $D$, et al. Induction of autophagy by spermidine promotes longevity. Nat Cell Biol. 2009;11:1305-14.

104. Chen J, Rao JN, Zou T, Liu L, Marasa BS, Xiao L, et al. Polyamines are required for expression of toll-like receptor 2 modulating intestinal epithelial barrier integrity. Am J Physiol Gastrointest Liver Physiol. 2007;293:G568-76.

105. Rao JN, Rathor N, Zhuang R, Zou T, Liu L, Xiao L, et al. Polyamines regulate intestinal epithelial restitution through TRPC1-mediated $\mathrm{Ca}^{2}+$ signaling by differentially modulating STIM1 and STIM2. Am J Physiol Cell Physiol. 2012; 303:C308-17.

106. Buts J-P, De Keyser N, Kolanowski J, Sokal E, Van Hoof F. Maturation of villus and crypt cell functions in rat small intestine. Dig Dis Sci 1993:38:1091-1098

107. Kibe R, Kurihara S, Sakai Y, Suzuki H, Ooga T, Sawaki E, et al. Upregulation of colonic luminal polyamines produced by intestinal microbiota delays senescence in mice. Sci Rep. 2014;4:4548. 
108. Haskó G, Kuhel DG, Marton A, Nemeth ZH, Deitch EA, Szabó C. Spermine differentially regulates the production of interleukin-12 p40 and interleukin10 and suppresses the release of the T helper 1 cytokine interferon-gamma. Shock Augusta Ga. 2000;14:144-9.

109. Bravo JA, Forsythe P, Chew MV, Escaravage E, Savignac HM, Dinan TG, et al. Ingestion of Lactobacillus strain regulates emotional behavior and central GABA receptor expression in a mouse via the vagus nerve. Proc Natl Acad Sci. 2011;108:16050-5.

110. Ko CY. Lin H-TV, Tsai GJ. Gamma-aminobutyric acid production in black soybean milk by Lactobacillus brevis FPA 3709 and the antidepressant effect of the fermented product on a forced swimming rat model. Process Biochem. 2013;48:559-68.

111. Pokusaeva K, Johnson C, Luk B, Uribe G, Fu Y, Oezguen N, et al. GABAproducing Bifidobacterium dentium modulates visceral sensitivity in the intestine. Neurogastroenterol Motil. 2017;29 https://doi.org/10.1111/nmo. 12904.

112. Bjurstöm H, Wang J, Wang J, Ericsson I, Bengtsson M, Liu Y, et al. GABA, a natural immunomodulator of T lymphocytes. J Neuroimmunol. 2008;205:44-50.

113. Bercik P, Verdu EF, Foster JA, Macri J, Potter M, Huang X, et al. Chronic gastrointestinal inflammation induces anxiety-like behavior and alters central nervous system biochemistry in mice. Gastroenterology. 2010;139:2102-12. el

114. Thomas CM, Hong T, van Pijkeren JP, Hemarajata P, Trinh DV, Hu W, et al. Histamine derived from probiotic Lactobacillus reuteri suppresses TNF via modulation of PKA and ERK signaling. PLoS One. 2012;7:e31951.

115. Elenkov IJ, Webster E, Papanicolaou DA, Fleisher TA, Chrousos GP, Wilder RL. Histamine potently suppresses human IL-12 and stimulates IL-10 production via H2 receptors. J Immunol. 1998;161:2586-93.

116. Baronio D, Gonchoroski T, Castro K, Zanatta G, Gottfried C, Riesgo R. Histaminergic system in brain disorders: lessons from the translational approach and future perspectives. Ann General Psychiatry. 2014;13:34.

117. Nuutinen S, Panula P. Histamine in neurotransmission and brain diseases. Adv Exp Med Biol. 2010;709:95-107.

118. Lyons DE, Beery JT, Lyons SA, Taylor SL. Cadaverine and aminoguanidine potentiate the uptake of histamine in vitro in perfused intestinal segments of rats. Toxicol Appl Pharmacol. 1983;70:445-58.

119. Le Gall G, Noor SO, Ridgway K, Scovell L, Jamieson C, Johnson IT, et al. Metabolomics of fecal extracts detects altered metabolic activity of gut microbiota in ulcerative colitis and irritable bowel syndrome. J Proteome Res. 2011;10:4208-18.

120. Gao J, Xu K, Liu H, Liu G, Bai M, Peng C, et al. Impact of the gut microbiota on intestinal immunity mediated by tryptophan metabolism. Front Cell Infect Microbiol. 2018;8:13.

121. Tourino MC, de Oliveira EM, Bellé LP, Knebel FH, Albuquerque RC, Dörr FA, et al. Tryptamine and dimethyltryptamine inhibit indoleamine 2,3 dioxygenase and increase the tumor-reactive effect of peripheral blood mononuclear cells. Cell Biochem Funct. 2013;31:361-4.

122. Islam J, Sato S, Watanabe K, Watanabe T, null A, Hirahara K, et al. Dietary tryptophan alleviates dextran sodium sulfate-induced colitis through aryl hydrocarbon receptor in mice. J Nutr Biochem. 2017;42:43-50.

123. Takaki M, Mawe GM, Barasch JM, Gershon MD, Gershon MD. Physiological responses of guinea-pig myenteric neurons secondary to the release of endogenous serotonin by tryptamine. Neuroscience. 1985;16:223-40.

124. Yano JM, Yu K, Donaldson GP, Shastri GG, Ann P, Ma L, et al. Indigenous bacteria from the gut microbiota regulate host serotonin biosynthesis. Cell. 2015;161:264-76.

125. Linden DR, Foley KF, McQuoid C, Simpson J, Sharkey KA, Mawe GM. Serotonin transporter function and expression are reduced in mice with TNBS-induced colitis. Neurogastroenterol Motil Off J Eur Gastrointest Motil Soc. 2005;17:565-74

126. Stasi C, Bellini M, Bassotti G, Blandizzi C, Milani S. Serotonin receptors and their role in the pathophysiology and therapy of irritable bowel syndrome. Tech Coloproctol. 2014;18:613-21.

127. Ramage AG, Villalón CM. 5-hydroxytryptamine and cardiovascular regulation. Trends Pharmacol Sci. 2008:29:472-81.

128. Ducy P, Karsenty G. The two faces of serotonin in bone biology. J Cell Biol. 2010;191:7-13.

129. Hall AB, Yassour M, Sauk J, Garner A, Jiang X, Arthur T, et al. A novel Ruminococcus gnavus clade enriched in inflammatory bowel disease patients. Genome Med. 2017;9:103.

130. Williams BB, Van Benschoten AH, Cimermancic P, Donia MS, Zimmermann $\mathrm{M}$, Taketani $\mathrm{M}$, et al. Discovery and characterization of gut microbiota decarboxylases that can produce the neurotransmitter tryptamine. Cell Host Microbe. 2014:16:495-503.

131. Bansal T, Alaniz RC, Wood TK, Jayaraman A. The bacterial signal indole increases epithelial-cell tight-junction resistance and attenuates indicators of inflammation. Proc Natl Acad Sci U S A. 2010;107:228-33.

132. Chimerel C, Emery E, Summers DK, Keyser U, Gribble FM, Reimann F. Bacterial metabolite indole modulates incretin secretion from intestinal Enteroendocrine L cells. Cell Rep. 2014;9:1202-8.

133. Steinert RE, Beglinger $C$, Langhans W. Intestinal GLP-1 and satiation: from man to rodents and back. Int J Obes. 2016;40:198-205.

134. Li G, Young KD. Indole production by the tryptophanase TnaA in Escherichia coli is determined by the amount of exogenous tryptophan. Microbiol Read Engl. 2013;159:402-10.

135. Meijers BKI, Evenepoel P. The gut-kidney axis: indoxyl sulfate, $p$-cresyl sulfate and CKD progression. Nephrol Dial Transplant. 2011;26:759-61.

136. Marcobal A, De las Rivas B, Landete JM, Tabera L, Muñoz R. Tyramine and phenylethylamine biosynthesis by food bacteria. Crit Rev Food Sci Nutr. 2012;52:448-67.

137. Shalaby AR. Significance of biogenic amines to food safety and human health. Food Res Int. 1996;29:675-90.

138. Pedersen G, Brynskov J, Saermark T. Phenol toxicity and conjugation in human colonic epithelial cells. Scand J Gastroenterol. 2002;37:74-9.

139. McCall IC, Betanzos A, Weber DA, Nava P, Miller GW, Parkos CA. Effects of phenol on barrier function of a human intestinal epithelial cell line correlate with altered tight junction protein localization. Toxicol Appl Pharmacol. 2009;241:61-70

140. Saito Y, Sato T, Nomoto K, Tsuji H. Identification of phenol- and p-cresolproducing intestinal bacteria by using media supplemented with tyrosine and its metabolites. FEMS Microbiol Ecol. 2018;94 https://doi.org/10.1093/ femsec/fiy 125.

141. Andriamihaja M, Lan A, Beaumont M, Audebert M, Wong X, Yamada K, et al. The deleterious metabolic and genotoxic effects of the bacterial metabolite p-cresol on colonic epithelial cells. Free Radic Biol Med. 2015;85:219-27.

142. Shiba T, Kawakami K, Sasaki T, Makino I, Kato I, Kobayashi T, et al. Effects of intestinal bacteria-derived p-cresyl sulfate on Th1-type immune response in vivo and in vitro. Toxicol Appl Pharmacol. 2014;274:191-9.

143. Ramakrishna BS, Roberts-Thomson IC, Pannall PR, Roediger WE. Impaired sulphation of phenol by the colonic mucosa in quiescent and active ulcerative colitis. Gut. 1991;32:46-9.

144. Watanabe H, Miyamoto Y, Honda D, Tanaka H, Wu Q, Endo M, et al. P-Cresyl sulfate causes renal tubular cell damage by inducing oxidative stress by activation of NADPH oxidase. Kidney Int. 2013;83:582-92.

145. Gabriele S, Sacco R, Cerullo S, Neri C, Urbani A, Tripi G, et al. Urinary p-cresol is elevated in young French children with autism spectrum disorder: a replication study. Biomarkers. 2014;19:463-70.

146. Shimazu S, Miklya I. Pharmacological studies with endogenous enhancer substances: beta-phenylethylamine, tryptamine, and their synthetic derivatives. Prog Neuro-Psychopharmacol Biol Psychiatry. 2004;28:421-7.

147. Santoru ML, Piras C, Murgia A, Palmas V, Camboni T, Liggi S, et al. Cross sectional evaluation of the gut-microbiome metabolome axis in an Italian cohort of IBD patients. Sci Rep. 2017;7:9523.

148. Clayton TA. Metabolic differences underlying two distinct rat urinary phenotypes, a suggested role for gut microbial metabolism of phenylalanine and a possible connection to autism. FEBS Lett. 2012;586:956-61.

149. Moss CW, Lambert MA, Goldsmith DJ. Production of Hydrocinnamic acid by clostridia. Appl Microbiol. 1970;19:375-8.

150. Lambert MA, Moss CW. Production of p-hydroxyhydrocinnamic acid from tyrosine by Peptostreptococcus anaerobius. J Clin Microbiol. 1980;12:291-3.

151. Shaw W. Increased urinary excretion of a 3-(3-hydroxyphenyl)-3hydroxypropionic acid (HPHPA), an abnormal phenylalanine metabolite of Clostridia spp. in the gastrointestinal tract, in urine samples from patients with autism and schizophrenia. Nutr Neurosci. 2010;13:135-43.

152. Lis AW, Mclaughlin I, Mpclaughlin RK, Lis EW, Stubbs EG. Profiles of ultraviolet-absorbing components of urine from autistic children, as obtained by high-resolution ion-exchange chromatography. Clin Chem. 1976;22:1528-32.

153. Cui $X$, Ye L, Li J, Jin L, Wang W, Li S, et al. Metagenomic and metabolomic analyses unveil dysbiosis of gut microbiota in chronic heart failure patients. Sci Rep. 2018;8:635.

154. van Duynhoven J, Vaughan EE, van Dorsten F, Gomez-Roldan V, de Vos R, Vervoort J, et al. Interactions of black tea polyphenols with human gut 
microbiota: implications for gut and cardiovascular health. Am J Clin Nutr. 2013;98:1631S-41S.

155. Luceri C, Giannini L, Lodovici M, Antonucci E, Abbate R, Masini E, et al. pCoumaric acid, a common dietary phenol, inhibits platelet activity in vitro and in vivo. Br J Nutr. 2007;97:458-63.

156. Mu H, Høy C-E. The digestion of dietary triacylglycerols. Prog Lipid Res. 2004;43:105-33.

157. Jaeger KE, Ransac S, Dijkstra BW, Colson C, van Heuvel M, Misset O. Bacterial lipases. FEMS Microbiol Rev. 1994;15:29-63.

158. Iqbal J, Hussain MM. Intestinal lipid absorption. Am J Physiol - Endocrinol Metab. 2009;296:E1183-94.

159. De Weirdt R, Possemiers S, Vermeulen G, Moerdijk-Poortvliet TCW, Boschker HTS, Verstraete W, et al. Human faecal microbiota display variable patterns of glycerol metabolism. FEMS Microbiol Ecol. 2010;74:601-11.

160. Vanhaecke L, Vercruysse F, Boon N, Verstraete W, Cleenwerck I, Wachter MD, et al. Isolation and characterization of human intestinal bacteria capable of transforming the dietary carcinogen 2-amino-1-methyl-6-phenylimidazo [4,5-b]pyridine. Appl Env Microbiol. 2008;74:1469-77.

161. Cleusix V, Lacroix C, Vollenweider S, Duboux M, Le Blay G. Inhibitory activity spectrum of reuterin produced by Lactobacillus reuteri against intestinal bacteria. BMC Microbiol. 2007;7:101.

162. Rath S, Heidrich B, Pieper DH, Vital M. Uncovering the trimethylamineproducing bacteria of the human gut microbiota. Microbiome. 2017;5:54.

163. Romano KA, Vivas El, Amador-Noguez D, Rey FE. Intestinal microbiota composition modulates choline bioavailability from diet and accumulation of the proatherogenic metabolite trimethylamine-N-oxide. mBio. 2015;6:e2481.

164. Wang Z, Klipfell E, Bennett BJ, Koeth R, Levison BS, DuGar B, et al. Gut flora metabolism of phosphatidylcholine promotes cardiovascular disease. Nature. 2011;472:57-63.

165. Koeth RA, Wang Z, Levison BS, Buffa JA, Org E, Sheehy BT, et al. Intestinal microbiota metabolism of $\mathrm{L}$-carnitine, a nutrient in red meat, promotes atherosclerosis. Nat Med. 2013;19:576-85.

166. Qi J, You T, Li J, Pan T, Xiang L, Han Y, et al. Circulating trimethylamine Noxide and the risk of cardiovascular diseases: a systematic review and metaanalysis of 11 prospective cohort studies. J Cell Mol Med. 2018;22:185-94.

167. Randrianarisoa E, Lehn-Stefan A, Wang X, Hoene M, Peter A, Heinzmann SS, et al. Relationship of serum trimethylamine $\mathrm{N}$-oxide (TMAO) levels with early atherosclerosis in humans. Sci Rep. 2016;6:26745.

168. Fennema D, Phillips IR, Shephard EA. Trimethylamine and trimethylamine Noxide, a Flavin-containing monooxygenase 3 (FMO3)-mediated hostmicrobiome metabolic axis implicated in health and disease. Drug Metab Dispos. 2016;44:1839-50.

169. Cândido FG, Valente FX, Grześkowiak $Ł M$, Moreira APB, Rocha DMUP, Alfenas R de CG. Impact of dietary fat on gut microbiota and low-grade systemic inflammation: mechanisms and clinical implications on obesity. Int J Food Sci Nutr. 2018;69:125-43.

170. Desbois AP, Smith VJ. Antibacterial free fatty acids: activities, mechanisms of action and biotechnological potential. Appl Microbiol Biotechnol. 2010;85:1629-42.

171. Huang S, Rutkowsky JM, Snodgrass RG, Ono-Moore KD, Schneider DA, Newman JW, et al. Saturated fatty acids activate TLR-mediated proinflammatory signaling pathways. J Lipid Res. 2012;53:2002-13.

172. Calder PC. N-3 fatty acids, inflammation and immunity: new mechanisms to explain old actions. Proc Nutr Soc. 2013;72:326-36.

173. Gregor MF, Hotamisligil GS. Inflammatory mechanisms in obesity. Annu Rev Immunol. 2011;29:415-45.

174. Bäckhed F, Manchester JK, Semenkovich CF, Gordon JI. Mechanisms underlying the resistance to diet-induced obesity in germ-free mice. Proc Natl Acad Sci U S A. 2007;104:979-84.

175. Desai MS, Seekatz AM, Koropatkin NM, Kamada N, Hickey CA, Wolter M, et al. A dietary fiber-deprived gut microbiota degrades the colonic mucus barrier and enhances pathogen susceptibility. Cell. 2016;167:1339-53. e21

176. Liang X, FitzGerald GA. Timing the microbes: the circadian rhythm of the gut microbiome. J Biol Rhythm. 2017;32:505-15.

177. Png CW, Lindén SK, Gilshenan KS, Zoetendal EG, McSweeney CS, Sly LI, et al. Mucolytic bacteria with increased prevalence in IBD mucosa augment in vitro utilization of mucin by other bacteria. Am J Gastroenterol. 2010;105:2420-8.

178. Dao MC, Everard A, Aron-Wisnewsky J, Sokolovska N, Prifti E, Verger EO, et al. Akkermansia muciniphila and improved metabolic health during a dietary intervention in obesity: relationship with gut microbiome richness and ecology. Gut. 2016;65:426-36.
179. Everard A, Belzer C, Geurts L, Ouwerkerk JP, Druart C, Bindels LB, et al. Crosstalk between Akkermansia muciniphila and intestinal epithelium controls diet-induced obesity. Proc Natl Acad Sci. 2013;110:9066-71.

180. Devkota S, Wang Y, Musch M, Leone V, Fehlner-Peach H, Nadimpalli A, et al. Dietary fat-induced taurocholic acid production promotes pathobiont and colitis in IL-10-/- mice. Nature. 2012;487:104-8.

181. Staley C, Weingarden AR, Khoruts A, Sadowsky MJ. Interaction of gut microbiota with bile acid metabolism and its influence on disease states. Appl Microbiol Biotechnol. 2017;101:47-64.

182. Carabotti M, Scirocco A, Maselli MA, Severi C. The gut-brain axis: interactions between enteric microbiota, central and enteric nervous systems. Ann Gastroenterol. 2015;28:203-9.

183. Tripathi A, Debelius J, Brenner DA, Karin M, Loomba R, Schnabl B, et al. The gut-liver axis and the intersection with the microbiome. Nat Rev Gastroenterol Hepatol. 2018;15:397-411.

184. Kamo T, Akazawa H, Suzuki J, Komuro I. Novel concept of a heart-gut axis in the pathophysiology of heart failure. Korean Circ J. 2017:47:663-9.

\section{Ready to submit your research? Choose BMC and benefit from:}

- fast, convenient online submission

- thorough peer review by experienced researchers in your field

- rapid publication on acceptance

- support for research data, including large and complex data types

- gold Open Access which fosters wider collaboration and increased citations

- maximum visibility for your research: over $100 \mathrm{M}$ website views per year

At BMC, research is always in progress.

Learn more biomedcentral.com/submissions 